удк 342.9

Д.В. Малишко

\title{
ПРАВОВІ ЗАСОБИ АДМІНІСТРАТИВНО-ПРАВОВОГО РЕГУЛЮВАННЯ У СФЕРІ МУНІЦИПАЛЬНОГО ТРАНСПОРТУ В УКРАЇНІ В КОНТЕКСТІ ВПРОВАДЖЕННЯ ІННОВАЦЙНИХ ТЕХНОЛОГІЙ ТА ІНФОРМАТИЗАЦІЇ ТРАНСПОРТНИХ МЕРЕЖ
}

Постановка проблеми. Сучасні тенденції інформатизації майже всіх сфер суспільного життя, впровадження інноваційних технологій значною мірою впливають на розвиток транспортної інфраструктури, адже саме в цій сфері суспільних відносин діють більшою мірою техніко-юридичні норми. Отже, в процесі адміністративно-правового регулювання у сфері муніципального транспорту в Україні необхідно враховувати ці тенденції та зосереджувати увагу на відповідній трансформації техніко-юридичних норм, серед яких особливе значення мають нормативні, ліцензійні вимоги, які пред'являються до перевізників, правила перевезення пасажирів та багажу всіма видами транспорту, нормативні положення щодо координації маршрутів та графіків руху муніципального транспорту.

Складовими частинами будь-якого механізму правового регулювання $є$ конкретні правові засоби, тому для сучасної науки адміністративного права важливим є доктринальний аналіз даної категорії, а також класифікація системи правових засобів адміністративно-правового регулювання у визначеній сфері суспільних відносин. Такий інструментальний підхід дозволяє максимально наблизити теоретичні розробки до потреб практики, запропонувати нормотворцям конкретні пропозиції щодо вдосконалення чинного та формування перспективного законодавства.

Методологія підготовки даної наукової публікації грунтується на органічному поєднанні загально-філософських, загальнонаукових та спеціально-юридичних методів дослідження, а також принципу об’єктивності. Більшою мірою використовувалися прийоми логічного методу, структурно-функціональний, системний метод та метод юридичного моделювання.

Складові частини механізму адміністративно-правового регулювання достатньо змістовно досліджені в роботах О. Бандурки, В. Бевзенка, Н. Губерської, С. Гусарова, Р. Калюжного, Т. Коломоєць, В. Колпакова, А. Комзюка, О. Кузьменко, В. Курила, Д. Лук'янця, Д. Лученка, Р. Мельника, О. Миколенка, Н. Нижник, Д. Приймаченка, С. Стеценко, М. Тищенка, А. Школика та інших учених-адміністративістів. Окремі аспекти адміністративно-правового регулювання у сфері транспорту проаналізовані в роботах В. Развадовського, П. Корнієнка, А. Подоляки, А. Присяжнюка, Є. Федорчука Т. Чернявської та ін. Проте дослідженню дієвих правових засобів адміністративно-правового регулювання у сфері муніципального транспорту приділена ще недостатня увага, що актуалізує проведення даного дослідження.

Метою статті $є$ визначення та класифікація субстанціональних та дієвих правових засобів адміністративно-правового регулювання у сфері муніципального транспорту в Україні в контексті впровадження інноваційних технологій та інформатизації транспортних мереж. 
Виклад основного матеріалу. У теорії держави і права категорію «правові засоби» окремо досліджували О.В. Онуфрієнко у праці «Правові засоби у контексті інструментальної теорії права» [1] та А.М. Денисова в роботі «Механізм і засоби правового впливу (теоретико-правове дослідження)» [2].

В останні роки категорію «правові засоби» активно використовують у своïх дослідженнях М.В. Буроменський, Д.О. Андреєв, Н.В. Аніщук, Т.В. Волинець, Н.В. Волкова, І.О. Дзера, Н.М. Дятленко, Г.В. Срьоменко, Б.В. Кузьменко, М.М. Кузьміна, О.С. Мірошниченко, О.О. Небрат, Є.Б. Ольховський, В.В. Пахомов, О.Ю. Салманова, О.О. Степанов, А.М. Чернобай та інші відомі науковці.

До правових засобів як складових частин механізму правового регулювання відносяться фактично всі елементи останнього, включаючи норми та принципи права, нормативно-правові акти, акти реалізації, тлумачення та застосування права. Універсальність категорії «правові засоби» дозволяє назвати їх інструментами юридичної діяльності. Такий інструментальний підхід дозволяє бачити у праві не тільки сукупність дозволів, заборон і зобов'язань, а дієву систему правових інструментів (засобів) досягнення приватної чи публічної мети правового регулювання.

Отже, цілком слушним є визначення, відповідно до якого правові засоби - це певні юридичні категорії та діяння суб'єктів із їх застосування з метою досягнення конкретного результату [3, с. 536$]$.

До субстанціональних правових засобів (засобів-постанов, інструментів) А.М. Денисова відносить зобов'язання, дозволи, заборони, заохочення, пільги, норми права, принципи права тощо, в той час як до дієвих (засобів-дій, технологій) - акти реалізації права, акти застосування права, акти тлумачення права і всі процеси юридичної діяльності. Усі правові засоби, на їі думку, в результаті узагальнення (трансформації) поділяються на правові стимули та правові обмеження. Правовий стимул визначається як засіб формування в суб'єкта необхідної законослухняної поведінки шляхом створення необхідних умов щодо задоволення суб'єктивних інтересів суб'єкта завдяки виконанню правових приписів. А правові обмеження - це правовий засіб стримування протиправного діяння, що створює умови для задоволення інтересів уповноваженого суб'єкта і суспільних інтересів в охороні й захисті [4, с. 191].

Таким чином, використання категорії «правові засоби» дозволяє надати дослідженню прикладного характеру та сформулювати конкретні пропозиції щодо вдосконалення чинного законодавства та юридичної практики.

Адміністративно-правове регулювання у сфері муніципального транспорту $є$ упорядкуванням публічно-правових відносин та встановленням за допомогою норм адміністративного права юридичних прав і обов'язків учасників правовідносин у галузі перевезення пасажирів та надання інших транспортних послуг на умовах організаційно-господарських договорів з органами місцевого самоврядування в межах адміністративно-територіальної одиниці, за допомогою транспортних засобів, які належать територіальній громаді або підприємцям, чим забезпечується якісне та своєчасне перевезення пасажирів та багажу муніципальним транспортом.

До основних нормативно-правових актів (субстанціональних правових засобів), які регулюють суспільні відносини у сфері муніципального транспорту, слід віднести: 
1) Ліцензійні умови провадження господарської діяльності з перевезення пасажирів, небезпечних вантажів та небезпечних відходів автомобільним транспортом, міжнародних перевезень пасажирів та вантажів автомобільним транспортом, затверджені Постановою Кабінету Міністрів України від 2 грудня 2015 року № 1001 (видані до набрання чинності Законом України «Про ліцензування видів господарської діяльності» ліцензії на право провадження господарської діяльності з надання послуг із перевезень пасажирів, небезпечних вантажів, багажу автомобільним транспортом $є$ чинними) [5];

2) Правила надання послуг пасажирського автомобільного транспорту, затверджені Постановою Кабінету Міністрів України від 18 лютого 1997 р. № 176 (у редакції постанови Кабінету Міністрів України від 26 вересня 2007 р. № 1184) [6] у відповідності до Закону України «Про автомобільний транспорт»;

3) Правила надання населенню послуг із перевезень міським електротранспортом, затверджені Постановою Кабінету Міністрів України від 23 грудня 2004 р. № 1735 [7] у відповідності до Закону України «Про міський електричний транспорт»;

4) Порядок проведення конкурсу з перевезення пасажирів на автобусному маршруті загального користування, затверджений Постановою Кабінету Міністрів України від 3 грудня 2008 р. № 1081 [8] (на підставі даної постанови органи місцевого самоврядування затверджують відповідні регіональні акти, як приклад - Положення про порядок проведення конкурсу на перевезення пасажирів автомобільним транспортом на автобусних маршрутах загального користування в місті Запоріжжя, затверджене Рішенням виконавчого комітету міської ради від 30.10.2006 p. № 390/1).

Ураховуючи перспективність розвитку мегаполісів та, відповідно, приміського залізничного транспорту, слід відзначити і такий відомчий нормативно-правовий акт, як Правила перевезення пасажирів, багажу, вантажобагажу та пошти залізничним транспортом України, затверджені Наказом Міністерства транспорту та зв’язку України від 27.12.2006 р. № 1196 [9].

Крім того, в найближчій перспективі очікується серійне виробництво компактних літальних апаратів, так званих аеромобілів, що буде вимагати розробки та прийняття відповідних нормативно-правових актів, створення відповідної інфраструктури та розгляду можливостей використання таких літальних апаратів у сфері муніципального транспорту. Зокрема, розглядається можливість використання безпілотних літальних транспортних засобів для створення мережі муніципальних аеротаксі. Керування такою мережею буде здійснювати комп'ютерна програма, яка буде регулювати графіки та маршрути (повітряні коридори) польотів із метою виключення людського фактору та запобігання можливим аварійним ситуаціям.

Наразі правове регулювання використання приватних літальних апаратів частково здійснюється Частиною 47 «Правила реєстрації цивільних повітряних суден в Україні» Авіаційних правил України, затверджених Наказом Державної авіаційної служби України від 05 лютого 2019 р. № 153 [10]. Зокрема, вказаними Правилами дається визначення такого транспортного засобу, як автожир - літальний апарат, важчий за повітря, що підтримується в польоті за рахунок взаємодії пові- 
тря з одним або декількома несучими гвинтами, які вільно обертаються навколо осей, що перебувають приблизно у вертикальному положенні [10]. Таким чином, цілком реальним і перспективним є використання таксі-дронів (квадракоптерів) із автоматизованими системами управління (автопілотом) у сфері муніципального транспорту. У перспективних Програмах розвитку та вдосконалення міського пасажирського транспорту доцільно передбачити впровадження інноваційних літальних транспортних засобів як додатку до мережі муніципального транспорту.

Важливе місце в механізмі правового регулювання у сфері муніципального транспорту посідають такі правові засоби, як програмні документи та стратегії розвитку транспортної галузі.

Так, Розпорядженням Кабінету Міністрів України від 30 травня 2018 р. № 430-р схвалено Національну транспортну стратегію України на період до 2030 року [11]. Вказана стратегія передбачає, зокрема, збільшення частки використання електротранспорту та електромобілів, зокрема доведення частки електротранспорту у внутрішньому сполученні до 75 відсотків у 2030 році.

Крім того, у відповідності до Національної транспортної стратегії України на період до 2030 року необхідним є розширення доступу до транспортних послуг i підвищення мобільності населення, що передбачає поліпшення сполучення між регіонами та в містах країни, зокрема для осіб з інвалідністю та інших маломобільних груп населення [11].

До загальних проблем, що потребують розв'язання, у вищезазначеній стратегії віднесено: низьку якість надання транспортних послуг із перевезення пасажирів; невідповідність законодавству СС системи замовлення соціальних зобов'язань та надання суспільно важливих послуг із перевезення пасажирів; зменшення провізної спроможності транспорту загального користування; зниження рівня життя мешканців сільської місцевості через відсутність регулярного забезпечення транспортними послугами; низький рівень доступності транспортних послуг та засобів, а також транспортної інфраструктури для осіб з інвалідністю та інших маломобільних груп населення; домінування в міських та регіональних перевезеннях видів транспорту з високим рівнем викидів вуглецю та сірки; збитковість приміських пасажирських перевезень залізничним транспортом та їх субсидування за рахунок вантажних; велику кількість пільгових перевезень (майже 20 млн. громадян мають право на пільги) та невирішене питання щодо їх монетизації чи компенсації за такі перевезення; низьку ефективність регулювання ринку перевезення пасажирів на таксі; обмежене бюджетне фінансування витрат, пов'язаних із наданням транспортних послуг із перевезення пасажирів, недосконалість процедури проведення конкурсів та укладення договорів про їх надання; відсутність системного контролю з боку організаторів перевезень та контролюючих органів за виконанням перевізниками умов договору про надання послуг на автобусних маршрутах загального користування, що не гарантує надання пасажирам якісних і безпечних послуг; недостатню мотивацію перевізників щодо інвестування для здійснення заходів із підвищення рівня якості та комфортності перевезень на автобусних маршрутах загального користування; неефективну і неконтрольовану систему оплати проїзду пасажирами на автомобільному транспорті; наявність недобросовісної конкуренції 
(наявність на ринку регулярних перевезень великої кількості перевізників, що провадять свою діяльність без відповідних дозвільних документів), що стримує інвестування перевізників у заходи з підвищення якості послуг пасажирського автотранспорту; високий рівень неофіційного працевлаштування працівників автомобільного транспорту; відсутність дієвої підтримки та популяризації велосипедного руху [11].

Ураховуючи вищезазначені проблеми, в Національній транспортній стратегії України на період до 2030 року визначено перелік завдань, що необхідно виконати, серед яких: забезпечення ефективного державного нагляду (контролю) за якістю надання транспортних послуг із перевезення пасажирів; протидія нелегальним перевезенням, створення умов для виходу перевізників із «тіні» та забезпечення легалізації доходів автомобільних перевізників; забезпечення розвитку мультимодальних пасажирських перевезень та запровадження «єдиного транспортного квитка»; впровадження контрактної форми взаємовідносин перевізників із місцевими органами виконавчої влади щодо замовлення соціальних зобов'язань та суспільно важливих послуг із перевезень пасажирів; лібералізація та дерегуляція ринку пасажирських автомобільних перевезень; запровадження стратегічного планування надання транспортних послуг у містах та прилеглих до міст територій як складової частини їх стратегічного планування розвитку, в тому числі з урахуванням забезпечення ефективного та зручного приміського сполучення між об'єктами транспорту (аеропорти, залізничні вокзали, морські та річкові порти, автовокзали тощо); виділення в містах окремих смуг руху для перевезення пасажирів; забезпечення інституціональної підтримки розвитку велосипедного руху, прийняття відповідних нормативно-правових актів щодо його участі в дорожньому русі; розроблення стратегії розвитку велосипедного руху, посилення велосипедної безпеки, яка б грунтувалася на прогресивному іноземному досвіді, та забезпечення розвитку інфраструктури для велосипедного руху; забезпечення розвитку соціально та екологічно орієнтованої мобільності на короткі відстані відповідно до моделей «Місто коротких шляхів» та впровадження принципів інтермодальності та забезпечення оптимальної взаємодії велосипедного руху з іншими видами транспорту; сприяння розвитку та популяризації авіації загального призначення, в тому числі шляхом спрощення процедур реєстрації, сертифікації та митного оформлення повітряних суден і надлегких літальних апаратів [11].

Важливим, у відповідності до Національної транспортної стратегії України на період до 2030 року, є підвищення якості пасажирських перевезень відповідно до законодавства ЄС шляхом: упровадження механізму систем управління якістю щодо пасажирських перевезень з обов'язковим оприлюдненням результатів діяльності; впровадження нових технологій та інтелектуальних транспортних систем для поліпшення якості надання транспортних послуг, систем інформування про надані послуги, впровадження електронної та інтегрованої автоматичної системи оплати проїзду; створення умов для заснування спільних компаній приміських пасажирських перевезень за участю місцевих органів виконавчої влади; забезпечення за участю місцевих держадміністрацій поетапної заміни автомобільного транспорту на електротранспорт, зокрема шляхом залучення кредитів на сприятливих 
умовах, удосконалення законодавства тощо; запровадження системи моніторингу дотримання прав пасажирів та критеріїв оцінювання якості послуг пасажирських перевезень, а також систем стимулювання перевізників за їх досягнення та дотримання соціальних нормативів; забезпечення доступності транспортних послуг для всіх громадян, у тому числі для осіб з інвалідністю та інших маломобільних груп населення, шляхом створення для них доступного середовища для вільного пересування; поступового оновлення рухомого складу для пасажирських перевезень, заміни видів транспорту з вуглецевими викидами, просування «зелених» видів транспорту, забезпечення розвитку велосипедного руху в містах, заміни концепції використання міні-автобусів на більш гнучкі та екологічно чисті системи, обладнані для перевезення осіб з інвалідністю та інших маломобільних груп населення; сприяння підвищенню міської мобільності та розвитку системи мережі паркувальних зон і пасажирських терміналів для пересадки з індивідуального транспорту на міський транспорт [11].

Таким чином, у Національній транспортній стратегії України на період до 2030 року певна увага приділена розвитку муніципального транспорту, проте більш ефективним убачається прийняття загальнонаціональної стратегії розвитку муніципального транспорту, яка буде деталізуватись на рівні місцевих програм. Наразі прикладом місцевих програм є Програма розвитку та вдосконалення міського пасажирського транспорту в місті Запоріжжя на 2017-2019 роки, затверджена Рішення міської ради № 36 від 25.01.2017 р.

До дієвих правових засобів (засобів-дій, технологій) адміністративно-правового регулювання у сфері муніципального транспорту в контексті впровадження інноваційних технологій та інформатизації транспортних мереж доцільно віднести:

1) подальшу імплементацію європейських норм і стандартів у сфері муніципального транспорту з урахуванням національних традицій;

2) правову регламентацію процесів інформатизації (діджиталізації) суспільних відносин у сфері муніципального транспорту;

3) створення автоматизованих систем контролю руху муніципального транспорту, його технічного стану, кількості перевезених пасажирів тощо;

4) створення автоматизованої системи оплати за проїзд у муніципальному транспорті з використанням транспортних телекомунікаційних мереж (Інтернет, мобільний зв'язок);

5) створення автоматизованих систем конкурсного відбору перевізників, які відповідають ліцензійним умовам надання послуг із пасажирських перевезень (виключення або мінімізація ролі чиновника в процесі ліцензування та конкурсного відбору перевізників);

6) прийняття єдиного нормативно-правового акта про муніципальний транспорт на рівні закону;

7) ухвалення загальнодержавної стратегії розвитку муніципального транспорту, місцевих програм на її реалізацію і щорічних планів виконання цих програм;

8) підвищення адміністративної відповідальності за використання смуг для руху муніципального транспорту приватними автомобілями із внесенням відповідних змін до КУпАП; 
9) адміністративно-правове врегулювання створення та функціонування автоматизованих систем управління муніципальним транспортом за технологією «штучного інтелекту» з використанням безпілотних транспортних засобів.

Висновки. За результатами проведеного дослідження пріоритетним напрямом удосконалення субстанціональних правових засобів регулювання правових відносин у сфері муніципального транспорту слід назвати прийняття перспективного закону України «Про муніципальний транспорт» із урахуванням європейських стандартів пасажирських перевезень. Крім того, перспективними дієвими правовими засобами адміністративно-правового регулювання у сфері муніципального транспорту є правова регламентація використання автоматизованих систем управління та контролю, технологій «штучного інтелекту» в організації муніципальних транспортних перевезень, а також енергоефективних технологій концепції «Місто коротких шляхів» із переважним використанням електротранспорту та розвитком велосипедної інфраструктури за прикладом та у відповідності до європейських стандартів.

\section{Jimepamypa}

1. Онуфрієнко О.В. Правові засоби у контексті інструментальної теорії права : автореф. дис. ... канд. юрид. наук : спец. 12.00.01; Національний ун-т внутрішніх справ. Харків. 2004. 18 с.

2. Денисова А.М. Механізм і засоби правового впливу (теоретико-правове дослідження) : дис. ... канд. юрид. наук : спец. 12.00.01. Національна академія внутрішніх справ МВС України. Київ. 2012. 230 с

3. Зайчук О.В. Теорія держави і права. Академічний курс : підручник. Київ : Юрінком Інтер, $2006.685 \mathrm{c}$.

4. Денисова А. Правові засоби: поняття та види. Право України. 2010. № 7. С. 190-195.

5. Про затвердження Ліцензійних умов провадження господарської діяльності з перевезення пасажирів, небезпечних вантажів та небезпечних відходів автомобільним транспортом, міжнародних перевезень пасажирів та вантажів автомобільним транспортом : Постанова Кабінету Міністрів України від 2 грудня 2015 року № 1001. Дата оновлення : 06.09.2016 p. URL : https://zakon.rada.gov.ua/laws/ show $/ 1001-2015-\%$ D0 $\%$ BF.

6. Про затвердження Правил надання послуг пасажирського автомобільного транспорту : Постанова Кабінету Міністрів України від 18 лютого 1997 р. № 176 (у редакції постанови Кабінету Міністрів України від 26 вересня 2007 р. № 1184). Дата оновлення : 17.03 .2018 p. URL : https://zakon.rada.gov. ua/laws/show $/ 176-97-\%$ D0 $\%$ BF.

7. Про затвердження Правил надання населенню послуг 3 перевезень міським електротранспортом : Постанова Кабінету Міністрів України від 23 грудня 2004 р. № 1735. Дата оновлення : 28.10.2017 p. URL : https://zakon.rada.gov.ua/laws/show/1735-2004-\% D0\% BF.

8. Про затвердження Порядку проведення конкурсу з перевезення пасажирів на автобусному маршруті загального користування : Постанова Кабінету Міністрів України від 3 грудня 2008 р. № 1081. Дата оновлення : 17.03 .2018 p. URL : https://zakon.rada.gov.ua/laws/show/1081-2008-\% D0\% BF.

9. Про затвердження Правил перевезення пасажирів, багажу, вантажобагажу та пошти залізничним транспортом України : Наказ Міністерства транспорту та зв'язку України від 27.12.2006 p. № 1196. Дата оновлення : 09.04.2019 p. URL : https://zakon.rada.gov.ua/laws/show/z0310-07.

10. Про затвердження Авіаційних правил України, Частина 47 «Правила реєстрації цивільних повітряних суден в Україні» : Наказ Державної авіаційної служби України від 05 лютого 2019 р. № 153. Дата оновлення : 05.02.2019 p. URL : https://zakon.rada.gov.ua/laws/show/z0240-19\#n11.

11. Про схвалення Національної транспортної стратегії України на період до 2030 року : Розпорядження Кабінету Міністрів України від 30 травня 2018 р. № 430-р. Дата оновлення: 30.05.2018 p. URL : https://zakon.rada.gov.ua/laws/show/430-2018- \% D1\% 80. 


\section{Анотація}

Малишко Д. В. Правові засоби адміністративно-правового регулювання у сфері муніципального транспорту в Україні в контексті впровадження інноваційних технологій та інформатизації транспортних мереж. - Стаття.

У науковій публікації досліджуються субстанціональні та дієві правові засоби адміністративно-правового регулювання у сфері муніципального транспорту. Відзначається, що перспективним правовим засобом $є$ регламентація використання автоматизованих систем управління, технологій «штучного інтелекту» в організації муніципальних транспортних перевезень.

Ключові слова: правові засоби, муніципальний транспорт, інформатизація, правила перевезень, транспортна стратегія, транспортні мережі, інноваційні технології, транспортні засоби.

\section{Аннотация}

Малышко Д. В. Правовые средства административно-правового регулирования в сфере муниципального транспорта в Украине в контексте внедрения инновационных технологий и информатизации транспортных сетей. - Статья.

В научной публикации исследуются субстанциональные и действенные правовые средства административно-правового регулирования в сфере муниципального транспорта. Отмечается, что перспективным правовым средством является регламентация использования автоматизированных систем управления, технологий «искусственного интеллекта» в организации муниципальных транспортных перевозок.

Ключевые слова: правовые средства, муниципальный транспорт, информатизация, правила перевозок, транспортная стратегия, транспортные сети, инновационные технологии, транспортные средства.

\section{Summary}

Malyshko D. V. Legal means of administrative and legal regulation in the field of municipal transport in Ukraine in the context of the introduction of innovative technologies and informatization of transport networks. - Article.

The scientific publication investigated the substantial and effective legal means of administrative regulation in the field of municipal transport. It is noted that a promising legal tool is the regulation of the use of automated control systems, technologies of "artificial intelligence" in the organization of municipal transport.

Key words: legal means, municipal transport, informatization, transportation rules, transport strategy, administrative regulation, transport networks, innovative technologies, vehicles. 